\title{
$\mathbf{X}$ 線反射投影を用いた埋もれた薄膜界面の可視化 ${ }^{\dagger}$
}

\author{
桜井 健次 ${ }^{1,2} \cdot$ 蒋 金星 ${ }^{2,1}$ \\ ${ }^{1}$ (国)物質・材料研究機構 荬305-0047 茨城県つくば市千現 1丁目 2-1 \\ 2筑波大学 凿305-0006 茨城県つくば市天王台 1丁目 1-1 \\ （2017 年 4 月 10 日受付；2017 年 4 月 28 日掲載決定）
}

\section{Visualization of Buried Interfaces of Thin Films by Using X-ray Reflection Projections}

\author{
Kenji SAKURAI ${ }^{1,2}$ and Jinxing JIANG ${ }^{2,1}$ \\ ${ }^{1}$ National Institute for Materials Science, 1-2-1 Sengen, Tsukuba, Ibaraki 305-0047 \\ ${ }^{2}$ Tsukuba University, 1-1-1 Tennodai, Tsukuba, Ibaraki 305-0006
}

(Received April 10, 2017 ; Accepted April 28, 2017)

\begin{abstract}
Exotic functions of thin films are quite often connected to the unique atomic and molecular features of buried layers and interfaces. In reality, the structures are far from uniform, but seeing such inhomogeneity is extremely difficult. The present research concerns how to solve the difficulty. The novel technique developed is the X-ray reflectivity imaging. While ordinary X-ray reflectivity gives very precise information on the electron density profile along the depth in thin films, the method can have some imaging capability, by combining with the image reconstruction scheme. Some practical applications will be reported.
\end{abstract}

KEYWORDS : X-ray reflectivity, buried interface, projection, visualization, image reconstruction

\section{1.は じめに}

薄膜の機能は, その膜構造, 界面構造に左右されるこ とが多く，構造を評価，検証する技術は不可欠である。 現状，電子顕微鏡等による断面観察が有力であるが，そ のような断面方向の構造が試料内の位置により異なるこ とが多くあり, 不均一さの解析もきわめて重要である。 特に非破壊的な測定法の登場は長く待望されていた。

本研究では, 埋もれた界面を非破壊的に可視化するた めに, X 線が薄膜の表面, 界面で反射する際に生じる投 影像を用いた技術開発を継続的に行っている ${ }^{1 \sim 6)}$ 。最近, 保護層に埋もれたラインパターン，厚さの異なるドッ 卜, 密度の異なるラインパターン等の非破壊的な可視化 や識別が行えること ${ }^{4}$, さらに微小ビームを使用せずに 微小領域の $\mathrm{X}$ 線反射率のプロファイルの取得も可能で あること ${ }^{6}$ などを報告した。本論文では，（1）異なる深

\footnotetext{
第 36 回表面科学学術講演会（2016 年 11 月 29 日～12 月 1 日）にて発表

E-mail : sakurai@yuhgiri.nims.go.jp
}

さに異なるパターン形状の金属超薄パターンがあるとき の重なりエリアの非破壊的な可視化, (2) コントラスト が必ずしも大きくない接着剤の紫外線硬化部の識別の二 つの未発表の事例をとりあげて議論する。

\section{2. 実 験 方 法}

\section{$2.1 X$ 線反射率法について}

物質の表面に入射したあらゆる電磁波は Snell の法 則 ${ }^{7)}$ に従い, 反射, 屈折する。X線は, 物質を構成する 電子の結合に関与する種々の共鳴周波数よりも高周波の 電磁波であることから，ほとんどの物質の屈折率が 1 よ り小さく，しかし非常に 1 に近い值を持つ。そのため, 平坦かつ平滑な物質表面に全反射臨界角よりも浅い角度 で入射した X 線は物質の外部で光学的な全反射を生じ る $^{8 \sim 12)}$ 。

$\mathrm{X}$ 線反射率とは, 全反射条件近傍での反射 $\mathrm{X}$ 線強度 と入射 $X$ 線強度の比のことであり，5８桁またはそれ 以上に及ぶログスケールで表現される。X 線反射率は, ほとんどの場合, 単色 $\mathrm{X}$ 線と位置分解能を持たないポ 
イント・ディテクターを用い, 微小角度域での $\theta / 2 \theta$ 角 度走査を行って取得されている。そのデー夕解析によっ て, 樑さ方向の電子密度の分布 (多層膜であれば各層の 密度, 膜厚, 各界面のラフネスなど）が求められる。X 線反射率法の実験, デー夕解析法等についてのさらに詳 しい内容は, 教科書 ${ }^{13)}$ や解説 ${ }^{14)}$ を参考にして頂きたい。

\section{$2.2 \mathrm{X}$ 線反射投影による界面可視化}

$\mathrm{X}$ 線反射率法による薄膜の解析では, 他の $\mathrm{X}$ 線技術 を用いる場合と同様, 暗黙のうちに試料の均一性を前提 としてデータを取り扱い, 議論している。しかし, 現実 に構造に関心を持ち, 解析を必要とする薄膜は, 必ずし も均一ではない。さまざまな機能や物性の差異は, その ような不均一さと関連していることも少なくない。さら には，積極的にある種の微細構造パターンを作りこんだ 薄膜・多層膜について, 解析を行いたい場合も多くあ る。このような試料について, これまでは不均一さを無 視してX 線反射率の測定を行うこともよく行われてい た。

だが,このとき，Fig. 1 に示すように，X 線検出器と して 1 次元または 2 次元の位置敏感型検出器を使用する と, 不均一さに対応した X 線の反射投影像が得られる。 $\mathrm{X}$ 線反射投影像を 1 次元の強度プロファイルとして採用 し, $\theta / 2 \theta$ 依存性を取得して, 2 次元画像としたものを reflectogram と呼ぶ。また, 特定の $\theta / 2 \theta$ 位置における 1 次元の分布を, 試料の面内角度依存性として収集し, 2 次元画像としたものを sinogram と呼ぶ。

Sinogram を取得して, コンピュータ・トモグラフィ と類似する画像再構成計算を行うと, 特定の $\theta / 2 \theta$ 地点 （特定の散乱ベクトル）におけるX 線反射率の試料内部

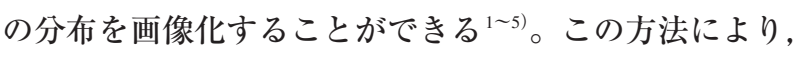
埋もれたパターンの形状を可視化し, 膜厚や密度のコン

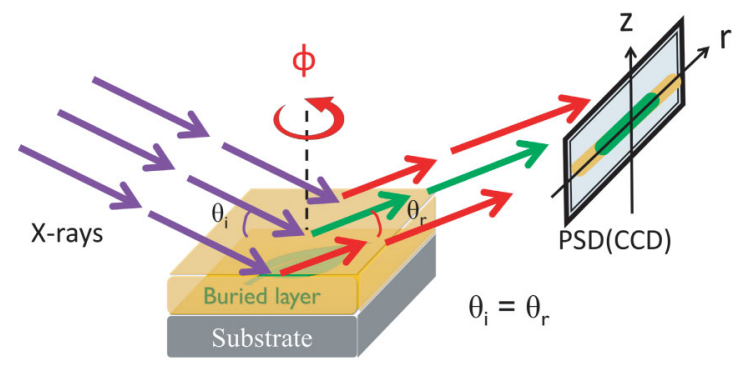

Fig. 1. (color online). Sketch to show the principle of X-ray reflectivity imaging. X-ray reflectivity sinogram is collected by setting a line focus $\mathrm{X}$-ray beam and a position sensitive detector, choosing an incident angle $\theta$, and rotating the sample in-plane to collect a series of reflectivity projections. The reflectivity image is obtained by an image reconstruction process.
トラストを画像化することができる。

さらに reflectogram を多くの面内回転角で収集し，3 次元的な sinogram を構築すると, 特定地点の $\mathrm{X}$ 線反射 率のプロファイルを抽出することができる ${ }^{14)}$ ここの方法 によって, 微小ビームを用いずに, 微小領域の薄膜構造 を解析できるようになった。空間分解能は現状 10〜20 $\mu \mathrm{m}$ 程度である。本研究では, シンクロトロン放射光を 用いた実験により多くのデー夕を収集したが，ょり広範 な学術研究や産業分野での利用も念頭において $15 \mathrm{~W}$ 程 度の低出力 $X$ 線源を用いた機器開発 ${ }^{6)} も$ 行っている。

\section{3. 実験結果・考察}

\section{1 埋もれた重なりのある金属超薄膜パターンの可 視化}

著者らは, 最近, 埋もれた超薄膜ラインパターンの可 視化, 厚さの異なるドットを識別した画像化, 異なる金 属のラインパターンを識別した画像化等において, X 線 反射率イメージングが効果的に適用できることを報告し た ${ }^{12)}$ 。本稿では, もう少し難易度の高い構造の試料を検 討した例を示したい。検討した試料の光学顕微鏡写真を Fig. 2 (a) に示す。シリコン基板（20 mm × $15 \mathrm{~mm} \times 2$ $\mathrm{mm}(\mathrm{t}))$ を用い, まず平均厚さ約 $150 \AA$ の三角形パター ンの金薄膜を堆積させ, 次に平均厚さ約 $160 \AA$ の均一な 銅薄膜で全面を被覆し, さらに平均厚さ約 $240 \AA$ の円形 パターンのジルコニウム薄膜を堆積させた。今回, 試料 内の特定視野では第 1 層のジルコニウムと第 3 層の金の パターンが重なっている部分がある。本研究では, この ようなエリアの非破壊的な可視化ができるかどうかの検 証を試みた。

高エネルギー加速器研究機構 ・ 放射光研究施設 BL14B において, $16.0 \mathrm{keV}$ の単色 X 線を用い, CCD カメ ラによって取得した reflectogram（反射投影 1 次元プロ ファイルの $\theta / 2 \theta$ 角度依存性）を Fig. 2 (b) に示す。こ の図の横軸は散乱べクトルを示しており, $\theta / 2 \theta$ 角度走 查を行った際の各角度位置に対応する。縦軸は試料の光 軸直行方向の座標である。X 線反射強度をログスケール で濃淡（疑似カラー）表示している。銅の $16.0 \mathrm{keV} に$ おける全反射臨界角は $3.63 \mathrm{mrad} て ゙$, 対応する散乱べク トルの Z 成分 Qzは $0.059 \AA^{-1}$ である。Fig. 2（b）の横 軸約 $0.059 \AA^{-1}$ 近傍より左側では顕著なコントラストが 見られず一様に高い反射強度が得られているのは, 試料 の全領域にわたって全反射が生じるためである。

Fig. 2 をよりよく検討するために, 試料の場所を光軸 直行方向の座標で 5 分類し, そのそれぞれについてその 領域を積分した X 線反射率のプロファイルをプロット した。その結果を Fig. 3 に示す。 
(a)

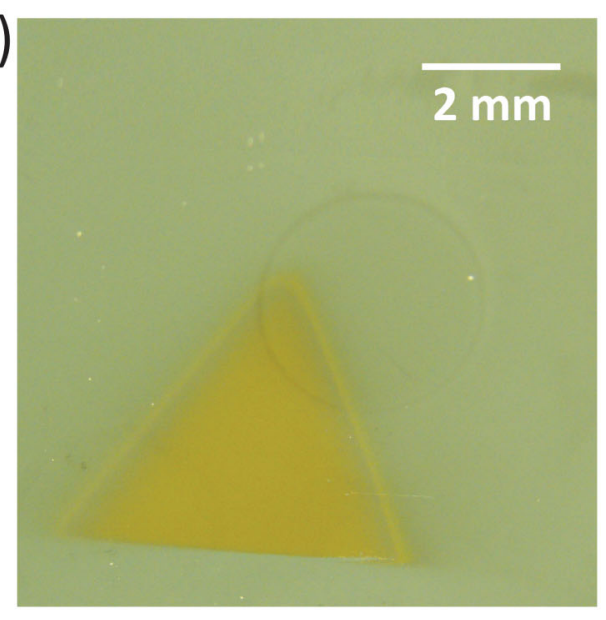

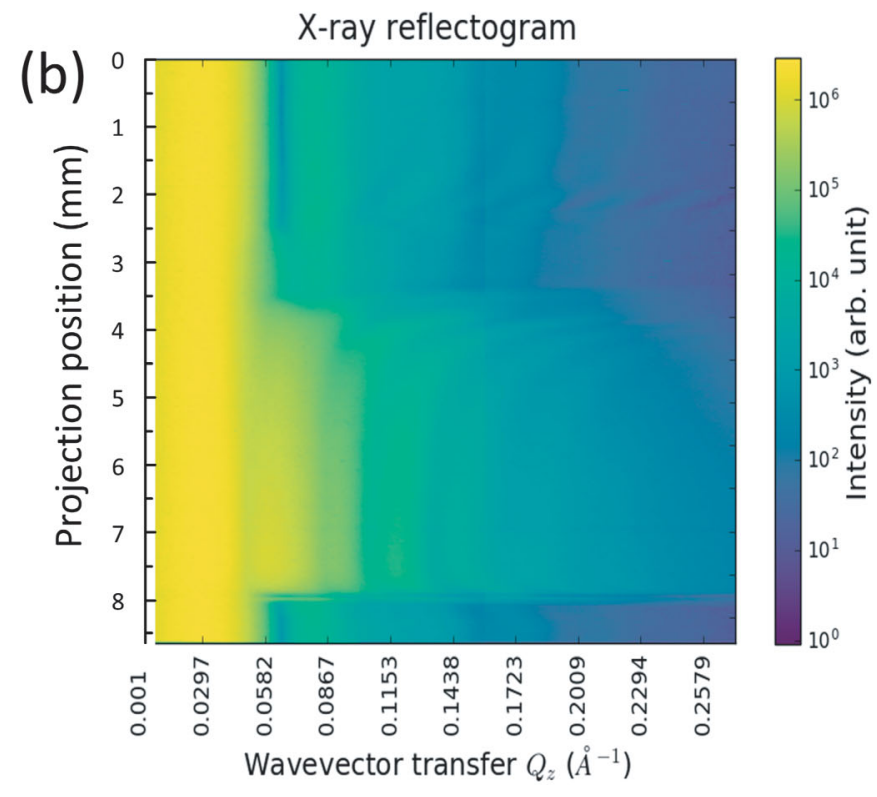

Fig. 2. (color online). (a) Optical image of the zirconium (pattern)/copper/gold (pattern)/silicon sample. (b) X-ray reflectograms of the zirconium (pattern)/copper/gold (pattern)/silicon sample plotted as a function of wavevector transfers Qzs at a specific in-plane angle, where the data are plotted on a logarithmic colorscale. The scanning step for the measurement is $\Delta \mathrm{Qz}=0.00057 \AA^{-1}$.
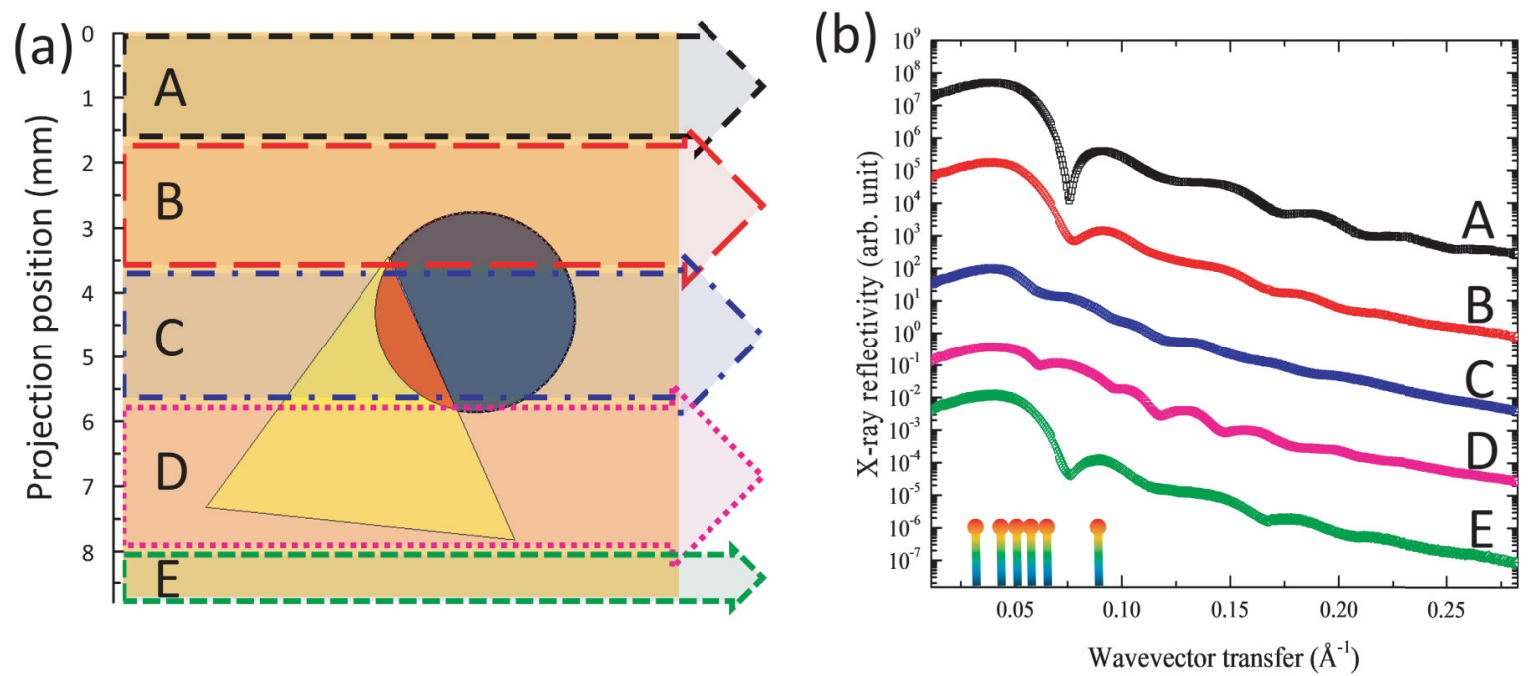
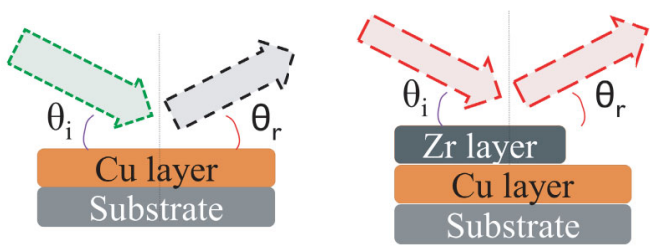

A, E

B

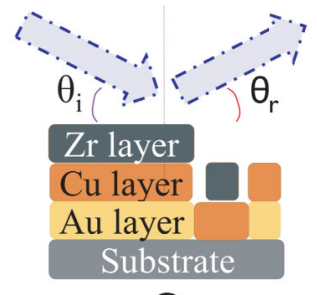

C

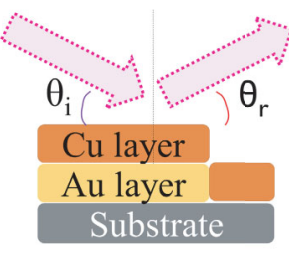

D

Fig. 3. (color online). (a) Sketch to show the main features of the zirconium (pattern)/copper/gold (pattern)/silicon sample. The arrows indicate the regions of interest for the X-ray reflectivity profiles in panel b. (b)X-ray reflectivity profiles of specific regions of interest extracted from the reflectogram in Fig. 2 (b). The 6 wavevector transfers used to obtain sonograms shown in Fig. 4 (a)-(f) are indicated on the abscissa. Bottom explanatory charts show the layers (or mixture of layers) included in the X-ray reflectivity profiles indicated. 


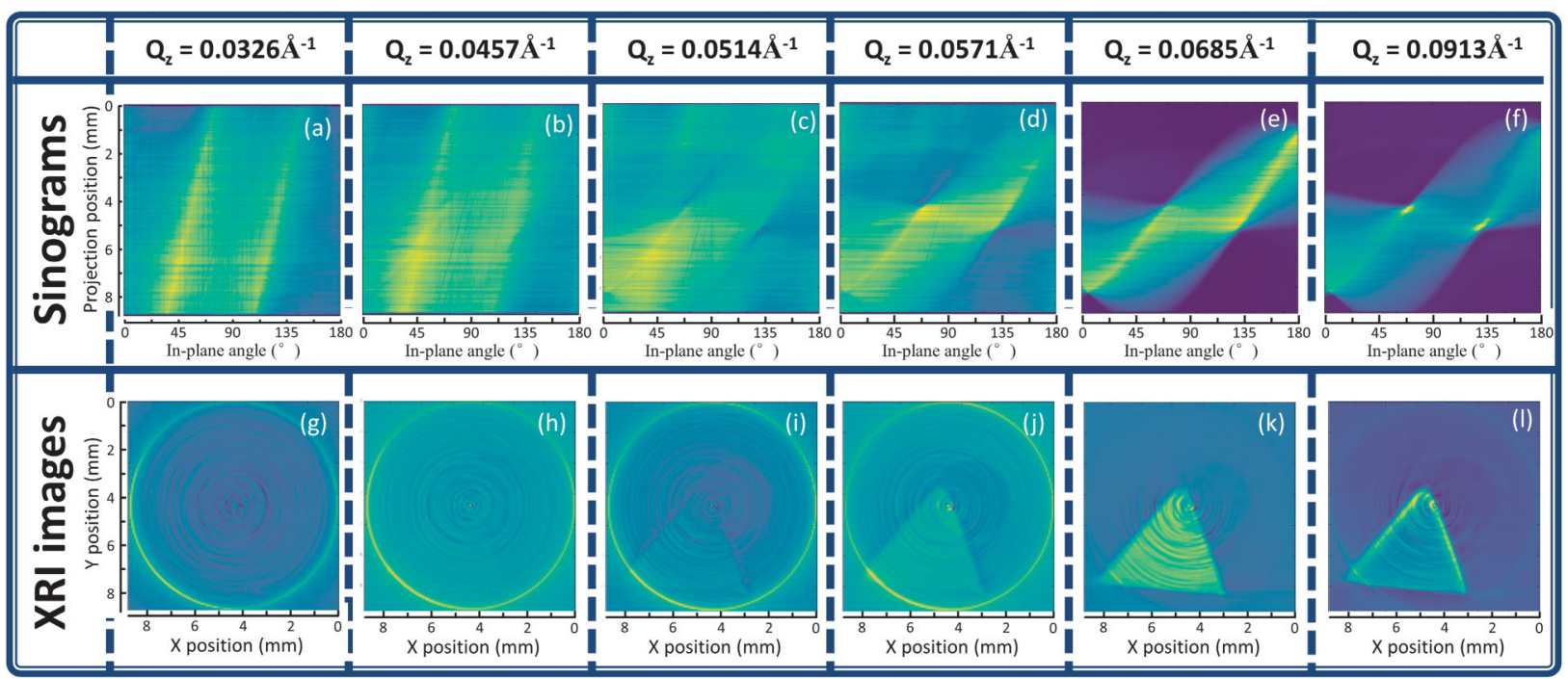

Fig. 4. (color online). X-ray reflectivity sinograms (the upper panel) and corresponding reconstructed images (the lower panel) of the zirconium (pattern)/copper/gold (pattern)/silicon sample at different wavevector transfers Qzs : (a) and (g) $\mathrm{Qz}=0.0326 \AA^{-1}$; (b) and (h) $\mathrm{Qz}=0.0457 \AA^{-1}$; (c) and (i) $\mathrm{Qz}=0.0514 \AA^{-1}$; (d) and (j) $\mathrm{Qz}=0.0571 \AA^{-1}$; (e) and (k) Qz= $0.0685 \AA^{-1}$; (f) and (l) $\mathrm{Qz}=0.0913 \AA^{-1}$. Any image corrections were not attempted to remove ring artifacts caused by inhomogeneity of the detector response.

この試料では，場所によって $\mathrm{Cu}$ 層しかない領域 $\mathrm{A}$ （0〜約 $1.6 \mathrm{~mm}$ 地点）および領域 $\mathrm{E}$ （約 $8 \mathrm{~mm}$ 地点〜 8.7 $\mathrm{mm}$ 地点), $\mathrm{Zr} / \mathrm{Cu}$ の 2 層構造の部位を含む領域 $\mathrm{B}$ (約 $1.6 \mathrm{~mm}$ 地点〜約 $3.6 \mathrm{~mm}$ 地点), $\mathrm{Zr} / \mathrm{Cu} / \mathrm{Au}$ の 3 層構造の 部位を含む領域 C (3.6 mm 地点〜約 $5.6 \mathrm{~mm}$ 地点), $\mathrm{Cu}$ / $\mathrm{Au}$ の 2 層構造の部位を含む領域 D（約 $5.6 \mathrm{~mm}$ 地点〜約 $8 \mathrm{~mm}$ 地点）があり，それぞれに異なるX 線反射率のプ ロファイルが得られることが明らかになった。従来，場 所による差異を無視し全部を積分してX 線反射率を求 めている応用例が多くあったが，このように反射投影の プロファイルに明暸な差異を見ることができ，それぞれ の情報を抽出することができる。特に今回注目したいの は $\mathrm{Zr} / \mathrm{Cu} / \mathrm{Au}$ の 3 層構造の部位を含むエリア $\mathrm{C}$ の $\mathrm{X}$ 線 反射率（正確には reflectogram の一部）が他とは明瞭に 異なるプロファイルである点である。膜構造が異なると $\mathrm{X}$ 線反射率のカーブにあらわれる干渉縞のパターンや周 期が異なるため, 散乱べクトルを注意深く選ぶと, その 差異を際立たせることができる。これを利用して，その エリアを画像として非破壊的に可視化することができな いかと考えた。

Fig. 4 の上段に示した（a)-(f) は，取得した sinogram の典型的なものである。それぞれ, 散乱べクトルを $0.0326 \AA^{-1}, \quad 0.0457 \AA^{-1}, \quad 0.0514 \AA^{-1}, \quad 0.0571 \AA^{-1}$, $0.0685 \AA^{-1}, 0.0913 \AA^{-1}$ に固定して, 試料を面内回転し て, 反射投影 1 次元プロファイルの面内角度依存性を取 得したものである。この五つの画像が相互に異なる画像
になっていることは, もちろん, 試料の膜構造の不均一 性に対応するものであり，構造情報が含まれている。な お，円周状のアーティファクトがどの画像にも乗ってい る $^{15,16)}$ 。主に検出器の応答性のわずかな不均一さに由来 するものであるが，本研究ではあえて除去処理などは行 っていない。

Fig. 4 の下段に示した（g)-(1) は，上段の sinogram を 2 次元フーリエ変換して画像再構成し, 実空間に打け るX 線反射率の面内分布を得たものである。順に見て ゆくと（g）はX 線反射強度にコントラストが生じない 全反射領域で取得されたものであり，まったくモノトー ンの画像になっている。（h）以後は， Qz を大きくし, ジルコニウム層 (円形), 金層（三角形）あるいは両者 の重なる部分の $\mathrm{X}$ 線反射率が強調されたり, 弱められ たりして，コントラストが順に変化するのに対応した画 像になっている。(g)〜 (1) は X 線反射率自体の画像で あるが，相対的に小さな変化を一層わかりやすく強調す るために，たとえば（j）と（k）について，Fig. 5 上部 に示す簡単な式による演算処理を行うと, Fig. 5 下部に 示すような画像が得られる。この画像では, $\mathrm{Zr} / \mathrm{Cu} / \mathrm{Au}$ の 3 層構造の部位が明瞭に可視化できている。この解析 の本質的な点は, 膜構造によるX 線反射率のプロファ イルの差異に着眼してコントラストを得ているところに ある。

以上のと抢り，X線反射率イメージングによって，同 一視野内に複数の重なりの層があるエリアを非破壊的に 


$$
f_{e}(x, y)=f_{1}(x, y)-f_{2}(x, y) \frac{\sum_{H i g h} f_{1}(x, y)}{\sum_{\text {High }} f_{2}(x, y)}
$$

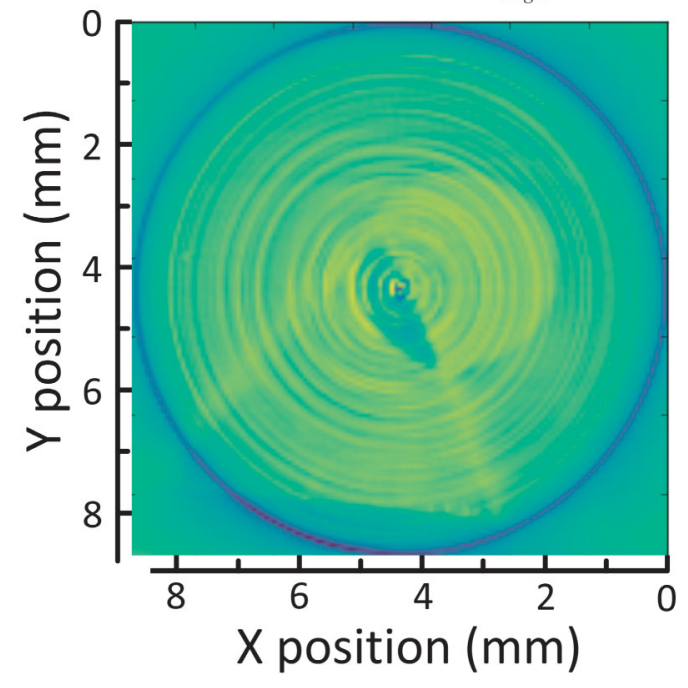

Fig. 5. (color online). A calculated X-ray reflectivity image to enhance the weak contrast pattern (zirconium/copper/ gold/silicon structure) by subtracting the Fig. 4 (k) by Fig. 4 (j) employing the formula at the top. Any image corrections were not attempted to remove ring artifacts caused by inhomogeneity of the detector response.
可視化できることが明らかになった。

\section{2 接着界面の可視化}

本研究では, 未知試料への適用も積極的に行ってい る。紫外線硬化型接着剤をスピンコート法でシリコン基 板上に作成した試料の reflectogram（反射投影 1 次元プ ロファイルの $\theta / 2 \theta$ 角度依存性を画像として表示したも の）を Fig. 6 (a) に示す（面内角は 0 度）。酸洗浄によ って親水性表面を持つように調整したシリコン基板（10 $\mathrm{mm} \times 10 \mathrm{~mm} \times 0.6 \mathrm{~mm}(\mathrm{t}))$ 上にトルエンに溶解した接着 片を滴下し，平均膜厚約 $1800 \AA ̊$ の膜を作成した。試料 のおよそ半分の領域（面内角が 0 度のとき，ほぼ Fig. 6 (a) 縦軸の 0〜約 $4.7 \mathrm{~mm}$ 地点に対応する) には $366 \mathrm{~nm}$ の紫外線を 2 分間照射して硬化させ, 残り半分（面内角 が 0 度のとき,ほほ Fig. 6 (a) 縦軸の約 $4.7 \mathrm{~mm}$ 地点 $\sim 8.7 \mathrm{~mm}$ 地点に対応する) はマスクして照射しないよ うにした。Fig. 6 (a) で, 横軸約 $0.03 \AA^{-1}$ (シリコンの 全反射臨界角に対応する）近傍より左側には場所による コントラストはないことなどは, 先の金属超薄膜の例と 同様である。先の金属超薄膜の場合には膜構造の差異に 対応する干渉縞の場所による違いを利用したが，そのよ うな差異が見えにくい場合にも, 特定の Qz 地点での強 度プロファイルを詳しく検討することができる。今回注 目している紫外線照射部（硬化部）と非照射部（非硬化 部）の差異を比較するため, $\mathrm{Qz}=0.0399 \AA^{-1}$ の地点で
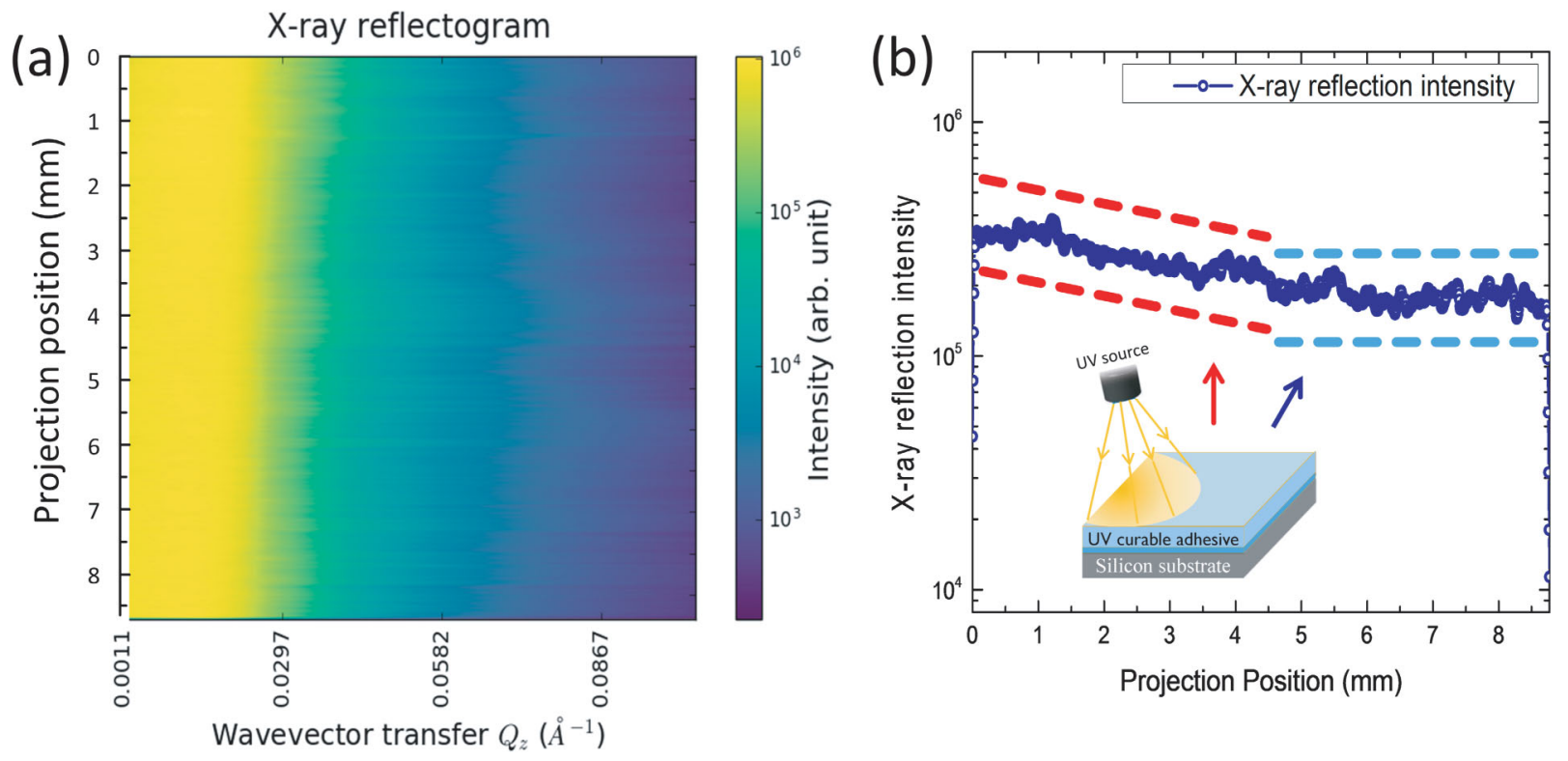

Fig. 6. (color online). (a) X-ray reflectograms of the ultraviolet curing adhesive/silicon sample plotted as a function of wavevector transfers Qzs at the specific in-plane angle $\phi=0^{\circ}$, where the data are plotted on a logarithmic colorscale. The scanning step for the measurement is $\Delta \mathrm{Qz}=0.00057 \AA^{-1}$. (b) The line slicing of the X-ray reflectogram at $\mathrm{Qz}=0.0399 \AA^{-1}$. The dashed lines serve as guide. Inset sketch shows the geometry the UV curing process, where the indicated region is the UV irradiated (cured) area. 

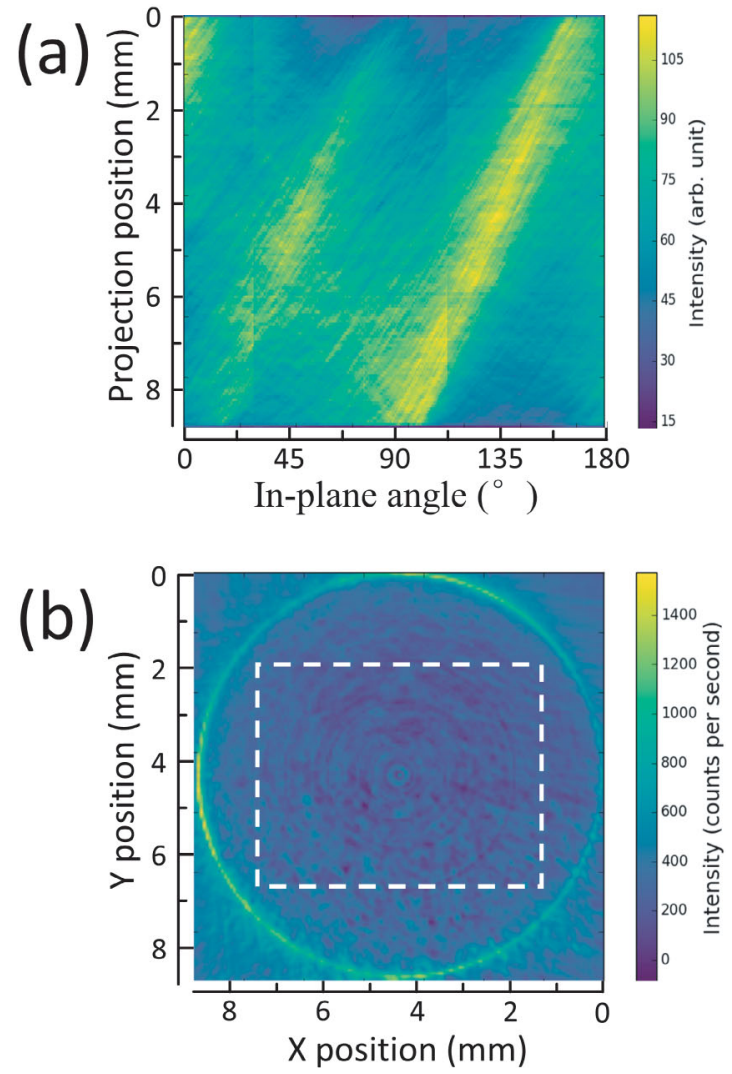

Fig. 7. (color online). (a) The X-ray reflectivity sinogram (the upper panel) and (b) the corresponding reconstructed image (the lower panel) of the ultraviolet curing adhesive/ silicon sample at the wavevector transfer $\mathrm{Qz}=0.0399 \AA^{-1}$. Any image corrections were not attempted to remove ring artifacts caused by inhomogeneity of the detector response. The white dashed lines indicate the region of interest for extracting the line profile (integrating along the $\mathrm{X}$ axis) in Fig. 8.

の X 線反射投影のプロファイル（強度の比較）を Fig. 6 （b）に示した。reflectogram はX 線進行方向に投影した ものであり，円形ではない試料を用いているとき，面内 角によって投影位置により積分している面積自体も異な り，したがって，X線反射の絶対強度そのものをそのま ま単純に使用するわけにはいかない点には注意する必要 がある。Fig. 6（b）では，紫外線照射部（硬化部）と非 照射部（非硬化部）の境界部分が見えていることに注目 するのがよい。

このような X 線反射投影の差異が得られる条件で, 面内角を変化させ， sinogram を取得した。さらにそれを 用いて画像再構成を行い，X線反射率の面内分布の画像 を得た。その結果をそれぞれ，Fig.7（a）と（b）に示 す。Fig. 7 （b）において，図の执よそ上半分（Yが0〜 約 $4.7 \mathrm{~mm}$ )，拈よそ下半分（Y が約 $4.7 \sim 8.7 \mathrm{~mm}$ ）が非

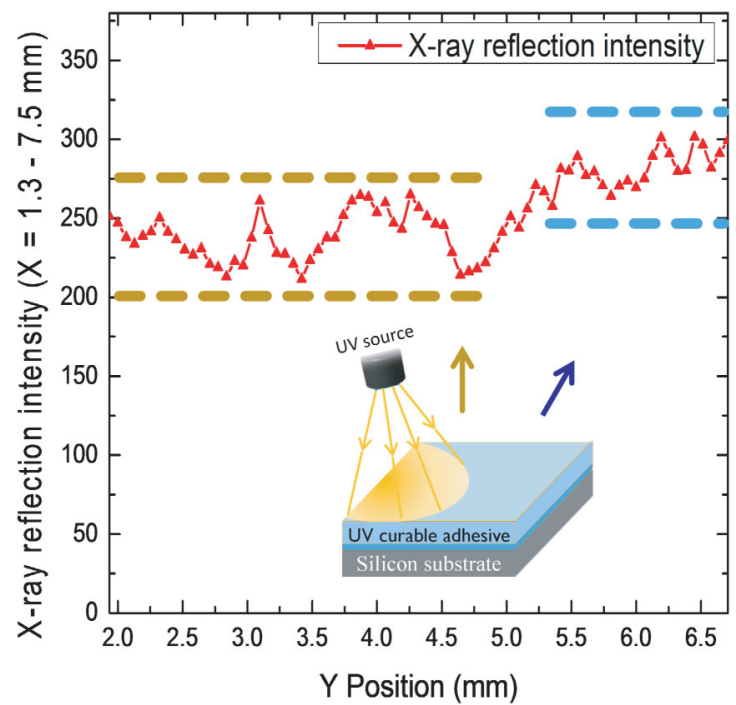

Fig. 8. (color online). The line profile (integrating along the $\mathrm{X}$ axis : $1.3 \mathrm{~mm}$ to $7.5 \mathrm{~mm}$, as the region of interest shown by the white dashed lines) in Fig. 7. The dashed lines serve as guide. Inset sketch shows the geometry of the UV curing process, where the indicated region is the UV irradiated (cured) area.

照射部である。この図では，下半分がやや明るく，相対 的にX 線反射率が高くなっているが，よりよく確認す るため, Fig. 8 に $=1.3 \mathrm{~mm} \sim 7.5 \mathrm{~mm}$ の間を積分して, $\mathrm{Y}$ 方向の $\mathrm{X}$ 線反射率の分布を図示した。紫外線照射部 (硬化部) と非照射部（非硬化部）では X 線反射率が約 $25 \%$ 違っており，この Qzでは, 紫外線照射部（硬化 部）のほうがX 線反射率は小さいことがわかる。イメ ージング実験とは独立して行った広面積の X 線反射率 の実験デー夕を解析した結果 ${ }^{17}$ から, 紫外線照射によっ て全膜厚は押よそ $2 \%$ 収縮し, 基板と膜の間に残存して いた低密度の空孔などが消滅して低密度層の密度が 6 $10 \%$ 回復すること等がわかっている。今回得られた画 像は，その考察ともよく対応している。

以上のと抒り，X線反射率イメージングによって，接 着剂の紫外線硬化部の非破壊的な可視化ができることが 明らかになった。この例は, X 線反射率のプロファイル 変化が比較的小さいケースに該当するが，それでも X 線反射率のプロファイルの差異が相対的に顕著な $\mathrm{Qz}$ を 選択することにより，紫外線硬化部とそうでない部分の 可視化は十分にできることがわかった。

本技術は新しく開発された方法であるため，現状では 再構成された $\mathrm{X}$ 線反射率もしくは $\mathrm{X}$ 線反射強度の画像 による解釈を中心に行ってきているが，今後，界面の密 着性のような関心に直結するパラメー夕を画像化するよ うな展開を意図している。これができるようになると， 
今後, 接着界面の kissing bonds ${ }^{18)}$ の検出, 可視化など, 接着不良部の出現にかかわる現象の解析等への応用が期 待される。これを行うためには, 試料内のそれぞれの地 点におけるX線反射率のプロファイルを抽出し ${ }^{14)}$, さ らに信頼できるモデルに基づいて構造パラメータを取得 する必要がある。この解析を安定的かつ高い信頼性で行 うためには, 現状では, まだ課題が残っている。

\section{4. ま め}

従来から知られている $\mathrm{X}$ 線反射率法を拡張し, イメ ージング機能を付加することにより, パターン構造や不 均一さを持つ薄膜・多層膜の埋もれた界面の非破壊的な 可視化が可能になった。 X 線反射率は膜厚, 密度, ラフ ネス（もしくは密度傾斜等の界面形状）の情報を解析す るッールであり, したがって, 試料上の場所による積層 構造や, 特定層の膜厚・密度の違い, 表面・界面形状の 違いをコントラストとして与えるイメージングが可能で ある。本論文では, 金属超薄膜の埋もれたパターンの重 なりの可視化の例と接着界面の解析の試みを報告した。

本研究の実験は, 高エネルギー加速器研究機構, 放射 光研究施設で行われた（課題番号 2015G053）。ビームラ インでは平野馨一博士のご支援を頂いたことを記して感 謝する。

\section{文献}

1) 桜井健次, 水沢多鶴子: 日本国特許第 5825602 号, (2015).
2) 兴井健次, 水沢多鶴子: 第 5935231 号(2016).

3) V.A. Innis-Samson, M. Mizusawa and K. Sakurai : Anal. Chem. 83, 7600 (2011).

4) J. Jiang, K. Hirano and K. Sakurai : J. Appl. Phys. 120, 115301 (2016).

5) J. Jiang and K. Sakurai : Rev. Sci. Instrum. 87, 093709 (2016).

6) J. Jiang, K. Hirano and K. Sakurai : J. Appl. Crystallogr. 50, 712 (2017).

7) M. Born and E. Wolf : "Principles of Optics 7th edition" (Cambridge University Press, 2000).

8) K. Stoev and K. Sakurai : Spectrochim. Acta, Part B 54, 41 (1999).

9) M. Tolan: "X-ray Scattering from Soft-Matter Thin Films” (Springer, 1999).

10) U. Pietsch, V. Holy and T. Baumbach : "High-Resolution X-ray Scattering From Thin Films to Lateral Nanostructures" (Springer, 2004).

11) J. Daillant and A. Gibaud (Eds.) : "X-ray and Neutron Reflectivity: Principles and Applications” (Springer, 2008).

12) J. Als-Nielsen and D. McMorrow : "Elements of Modern X-ray Physics” (John Wiley \& Sons, 2011).

13) 桜井健次編: “X 線反射率法入門” (講談社サイエンテ イフィク, 2009).

14) 桜井健次 : 応用物理 78, 224(2009).

15) C. Raven : Rev. Sci. Instrum. 69, 2978 (1998).

16) J. Sijbers and A. Postnov : Phys. Med. Biol. 49, 247 (2004)

17) J. Jiang : 筑波大学博士論文(2017).

18) C.J. Brotherhood, B.W. Drinkwater and S. Dixon: Ultrasonics 41, 521 (2003). 